ROCZNIKI HUMANISTYCZNE

Tom LXVIII, zeszyt $12-2020$

DOI: https://doi.org/10.18290/rh206812-11

OLGA BALLENGEE

\title{
JOHN CAGE, FLUXUS \\ AND THE MUSICALITY OF NAM JUNE PAIK
}

Despite his later notoriety as "the father of video art," Nam June Paik trained as a musician in Japan and came under the influence of John Cage while both were in Germany in the late 1950s. Paik's avant-garde violin and cello compositions from subsequent decades are often categorized as "performance art", a term that came of age during this period but one that ignores the musicality of Paik's composition as it extends from Cage's notion of music as action. In this paper, I offer an analysis that suggests these compositions, especially those from the 1960 s, are essentially musical, in the Cagean sense of the term, since aural, visual, and theatrical elements are compositionally integrated into works in which performance becomes a unifying and meaninggenerating force. I conclude by suggesting that Cage's influence on Paik was indeed profound, setting the tone for Paik's expansion into experiments with television and video that would occupy him for the remainder of his career.

After studying Schoenberg and Webern as a university student, Paik attended the Darmstadt International Summer Courses for New Music in 1958. While there, he met Cage, whose influence marked a shift in Paik's music toward more spontaneous forms of composition as he became disillusioned with the expressive possibilities of serialism. Paik quickly embraced the theatricality of Cage's compositions. Where Cage's work tended to value subtlety, Paik, on the other hand, acquired a reputation for confrontational and even violent performances. Allan Kaprow recalls his first encounters with Paik:

Nam June Paik was first known to us in the early sixties as a cultural terrorist. This man of solid pursuits in art history, musicology, philosophy, and technology — so

Olga BALlengeE - independent scholar, ethnomusicologist, Maryland, USA; e-mail: olgaballengee@gmail.com. 
utterly at home in the caultures of East and West - shocked his musical audiences: sudden rippings of others' neckties; his soap-lathered head plunging, screaming into a washtub, nearly drowning; his demolitions of pianos. Paik was the all-too-live embodiment of his ironic assertion that the relative is the absolute, and vice versa (Kellein and Stooss 114).

The "us" Kaprow refers to is Fluxus, the international avant-garde network of artists organized by George Maciunas beginning in 1961. Philip Auslander traces the beginnings of Fluxus to Cage's course on experimental music taught at the New School for Social Research in 1958 (114). Alumni from this course included the likes of George Brecht, Kaprow, and Dick Higgins, among others.

Their experience with Cage's liberal interpretation of music was a force of cohesion, one that held even more tightly when Maciunas entered the frame. At first hosting avant-garde performances in his art gallery, Maciunas founded, named, and appointed himself leader of the group. He also organized and created promotional material for exhibitions and performances, produced and distributed a Fluxus newsletter, and according to differing accounts determined the membership of Fluxus based upon criteria that was subject to change at a moment's notice. Despite Maciunas' moody leadership (or maybe because of it), Fluxus maintained a membership that was close-knit, yet appropriately in flux as individuals were invited to, disinvited from, or voluntarily left the group.

In general, Cage's musical philosophy was an inspiration for Fluxus artists, who were focused upon delegitimizing conventional conceptions of art. Cage often characterized his work simply as another stage in the development of music, yet his compositions nonetheless were critical of Western musical norms. As early as 1937, Cage had lamented that music was not moving forward, that "we are shielded from new sound experiences" by continuing to rely upon $18^{\text {th }}$ and $19^{\text {th }}$ century musical conventions (Cage 4). Cage's basic definition of music was always "the organization of sound" as is cited in many of his writings, lectures, and interviews. However, the Cagean musical aesthetic from the 1950s onward, affected profoundly by Zen Buddhism, chance composition, and indeterminacy, went beyond the simple organization of sound to include the organization of action as well. As Cage might have argued, action produced sounds, thus action should also be considered an aspect of music. As such, Cage scores from the 1960s began to include written instructions for actions to be completed by the performers, sometimes with or without the accompaniment of conventional or modified staff notation. 
Inspired in part by Cage, the eclectic works created by many Fluxus members were often cast "under the traditional rubric of music" but included aspects of theatre, visual art, poetry, and other artistic disciplines (Auslander 113). The Fluxus notion of music constituted a "conceptual constellation" of artistic action that allowed for music to be understood in a broadly performative way (Shaw-Miller 209). Though comparisons with early $20^{\text {th }}$ century dada are often made with the work of Fluxus, there are certainly some ideological differences. Most importantly, the Dadaists created works that highlighted what they perceived as the meaninglessness of the modern world, a meaninglessness made all the more apparent by the devastation of World War I. Fluxus artists by contrast tended to create works that embraced modernity as they appropriated and reflexively critiqued the bourgeois category of "art", taking great delight in dismantling the tools of what they viewed as elite culture in vivid, confusing, and often dramatic ways.

Whether through direct imitation of Cage's "action music", as Paik called it, or through independent discoveries of their own, many Fluxus artists, including LaMonte Young, Yoko Ono, and especially George Brecht, produced event scores that constituted the bulk of Fluxus' early printed output. Often these scores were brief enough to fit on small paper cards that were collected by Maciunas into displays he called "boxed multiples", allowing gallery attendees to explore the cards at their leisure and give intimate self-performances if they so desired. Other times, event scores were meant for staged performances. In the score for his Solo for Violin (1962), for example, Maciunas directs the performer in specific ways to methodically deconstruct the instrument. The full text of the score reads: "Old classic is performed on a violin. Where pauses are called, violin is mistreated by scratching the floor with it, dropping pebbles through the $f$ hole, pulling out pegs, etc." (Friedman at al.).

Here the violin becomes the object of Maciunas' frustration with "a high culture in thrall to the music of dead composers" (Hamlyn 13). As a symbol of bourgeois detachment, the instrument is ridiculed by subjecting it to surreal and destructive playing techniques during the performance of an "old classic." This pattern of violence toward the old way of doing things would come up again and again in the work of Fluxus members, especially Paik among them.

Paik's work fits within the tenets of Fluxus ideology, underscoring the irrelevancy of elite art by re-appropriating symbols of high culture in ways that position them as objects of ridicule, violence, and often transformation. Furthermore, Paik's work-especially in the 1960s and 1970s-reflects the Fluxus aesthetic, one that operates in the spaces between the aural, visual, and 
performative aspects of traditional art. And despite its often surface-level schizophrenia, I see Paik's composition as essentially musical, emerging primarily from Cage's influence but developing in unique ways over time. The strongest Cagean characteristic in Paik's early compositions is the re-conceptualization of music as a realm of not only sound, but also action.

This concept is exemplified in Cage's 4'33" No. 2 or 0'0" (1962), in which the score consists of only simple instructions: "In a situation provided with maximum amplification (no feedback), perform a disciplined action". The first performance of this piece, as noted in the score, was when Cage wrote that very sentence. The conceptual lead up to 0 ' $00^{\prime \prime}$ can be sensed in previous works like Water Walk (1959), composed by Cage for presentation on Italian television. The piece called for a number of actions involving water, including the release of steam from a pressure cooker, blending of ice, pouring and drinking a glass of water, and dipping a small gong into a tub of water. As with many of his other works from this time, Cage also included electronic sounds as well, in this case sounds emanating from a tape recorder and five radios. Interestingly, Cage also performed Water Walk on the CBS game show "I've Got a Secret" in the early 1960s where he was introduced as "the most controversial figure in the music world today" (John Cage-Water Walk). It is telling that Cage intended the piece as a "solo television performance." The use of radios in a piece otherwise scored for water-related instruments and the choice to use television as a performance medium foreshadowed Paik's electronic experiments only a few years later.

When asked by the host of "I've Got a Secret" if he actually considered Water Walk music, Cage responded, "I consider music the production of sound, and since, as you will hear in the piece, I produce sounds, I would call it music" (John Cage-Water Walk). As Cage suggests here, sounds would be impossible to make without the action required to produce them, action that, as the title of the piece implies, also includes walking between the individual instruments. Thus, even the actions taken to compose (as in $0^{\prime} 00^{\prime \prime}$ ) and perform a piece of music can for Cage conceivably be musical actions.

This extension of music from soundscape to that of action-scape stems from Cage's earlier indeterminate compositions that give the performer space to interpret the score within given parameters. By giving performer's this freedom, Cage allowed for performance to become a central aspect of his music. Like indeterminacy, Cage's development of chance composition techniques was further intended to produce music that was ironically without intention. Speaking after a performance in 1976 of Atlas eclipticalis - a piece composed 
by overlaying star charts on staff paper resulting in a collection of motifs to be played indeterminately by an orchestra and ad lib electronics - a delighted Cage claimed that it "doesn't have any of my ideas or any of my feelings in it-it's just sounds" (Griffiths 39).

However, we cannot always take the composer at his word, for it is certainly not composed of "just sounds", but also actions if we are to believe the clues he leaves in other compositions and writings from this period. To borrow Shaw-Miller's characterization of Fluxus' musical output, Cage's work is a "conceptual constellation" combining the visual aspects of the score, the aural aspects of the music, and the theatrics of action unified and activated through performance (209).

This seems to be have been an attractive concept for Paik. In a mini-manifesto on a coming "paperless society" (an essay that in form closely resembles some of Cage's lectures from Silence), Paik gives a diagrammatic explanation of the development of Western art music, beginning with medieval music and tracing through various periods of history ("Expanded" 7). Immediately following serialism, Paik situates an era of "Action or Event Music" beginning in the 1950s, clearly indicating the regard he had for composers like Cage and Brecht.

Unlike these composers, however, Paik left little in the way of written performance scores. Criticizing the likes of Brecht whose scores primarily consisted only of ambiguous written instructions, Paik suggests that recorded video might be a "useful supplement for their sketchy instructions" ("Expanded" 7). Elsewhere, Paik similarly declared that "paper is dead, except for toilet paper" ("TV"). Given his disdain for paper, scores for Paik's compositions of this era are either nonexistent or difficult to find and thus offer little help in analyzing his work. And though we have a good audio/visual record of Paik's performances from the 1970s and after as his video installations began to be regarded as mainstream art, the compositions he created immediately after meeting Cage are preserved only in anecdotes, a few photographs, and after-the-fact re-performances by contemporary performers. (Paik and Hanhardt; Kellein and Stooss).

Perhaps more than any other of his compositions, Paik's Violin with String (1961) and One for Violin Solo (1962) embody the Fluxus/Cage influence. As performance pieces, they run parallel to the notion of the delegitimization of art promoted by the Fluxus group while simultaneously connecting actions with the processes of music. Violin with String (1961) is a performance piece in which Paik attaches a string to a violin and drags it while he walks, the idea being that 
sounds emanate from the violin as it randomly bounces along. In the process the instrument gathers scars, gouges, and other bruises that both affect the sound and image of the instrument by the end of the performance. In One for Violin Solo, an even more violent piece that Paik is only known to have performed once in 1962, the performer slowly raises a violin over the course of about five minutes, then suddenly smashes it on a table, breaking the heretofore silence with one loud crash. The instrument in both compositions becomes the target of the composer's frustration. As it is destroyed, the composer also symbolically destroys the strictures of high art that it represents. Both pieces stem from simple ideas about sound and action. However, they diverge from Cage both in their discernable narrativity and their lack of subtlety.

One for Violin Solo in particular occupies a place in musical culture quite similar to Cage's 4'33" in that both are very easy to perform and even today provide both amusement and amazement in their simplicity. In 4'33', the audience waits for something to happen or, for those in the know, experiences the performer's silence with the expectation that any small or large sound is an integral part of the piece. A very different kind of tension is present in One, however. Given the more perceptible action of the performer (i.e. gripping the neck of the violin with both hands while it is raised above the head), the audience tends to expect the violin to come crashing down. Even if Paik had chosen to not smash the violin, the action being performed is more predictable than that of a performer simply sitting at a piano with a stopwatch. Thus, the actions performed in One imply a perceivable, though not wholly predictable, narrative that upon first encounter is more easily understood (i.e. "he smashed a violin") than is that of 4'33" (i.e. "is he going to do anything?"). Thus, Cage's 4'33" is indeed more subtle, requiring repeated exposure and explanation for the average audience member to understand why the performer is not doing anything. And by contrast, Paik's One is more in-your-face, understood at least on the most basic level by first time viewers as an action that produces some immediate result. Cage cultivated chance and indeterminacy to keep himself from inserting a pre-programmed narrative into the music. By contrast, Paik's compositions imply a sense of intention that is often lacking in Cage's calculated methodology, though Paik certainly employed indeterminate elements in many of his compositions.

The first major exhibition of Paik's work, set in Wuppertal, Germany in 1963, was titled "Exposition of Music: Electronic Television". This marked the beginning of Paik's use of television sets as an integral component of his compositions, though television constituted only a small part of the exhibition. Also 
included were four "prepared" piano sculptures to which Paik had attached various discarded materials, including electronics, clothing, lamps, alarm clocks, eggshells, photographs, wires of all sorts, and other garbage. All the pianos were deconstructed to varying degrees and at least one was completely destroyed by the end of the evening's exhibition by gallery attendees.

This exhibition also marks a transition for Paik, turning from an aesthetic characterized by violence and destruction, to one highlighting the possibilities of technology to create a new kind of art. In addition to the prepared pianos, various sculptures, and a freshly severed ox head, Paik included works that drew upon the active manipulation of technology, deconstructing magnetic tape and cathode ray tubes to create something new and unexpected. In Random Access, for example, spectators are directed to run a cassette player's play head across strips of pre-recorded magnetic tape mounted on a wall, in effect allowing for everchanging collages of sound. But most important at the exhibition was indeed Paik's Manipulated Television, an installation consisting of thirteen television sets manipulated in various ways to affect the images on screen. Some were turned upside down, some had their vertical or horizontal controls adjusted, and some were manually prepared by Paik in an improvisational fashion.

Random Access and Manipulated Television, very much reflect Cage's indeterminate and performative influence. These works suggest that performance activates the expressive capabilities built into the framework of composition. Without action, Random Access would only be tape on a wall and Manipulated Television would be simply television. These works' setting within the larger context of "Exposition of Music: Electronic Television," however, also points to Paik's tendency toward the Fluxus ideology of delegitimizing high art. With Manipulated Television in particular, Paik appropriates the television, a consumer electronic device that had quickly become the very center of popular culture at the time, and transforms it into a performative medium that at once celebrates and transcends its humble status. As Kaprow suggests about Paik's video art in the 1960s and 1970s, "he destroys the TV sets' normal function as he destroyed the piano's (...) but out of electronic devastations emerge miraculous visual joys" (Kellein and Stooss 114).

Paik's collaborations with cellist Charlottle Moorman represent a marriage of his early action music with indeterminate video manipulation. Paik's works for TV Cello (1971), for example, were created for Moorman based upon Paik's experiments with video synthesis. The TV Cello consists of three cathode ray tubes, encased in plexiglass, stacked one on top of another to form a cello shape, with cello strings running the length of the instrument. In perfor- 
mance, the sounds that Moorman produced were electronically converted into abstract images that played back on the tubes within the cello. Improvised by Moorman, the sound of the cello-including a number of extended playing techniques, among them long glissandos, harmonics, and a myriad of percussive effects - was electronically manipulated in various ways as well.

The TV Cello was often incorporated into other of Paik's works, including a demonstration for Paik's PBS special entitled "Good Morning Mr. Orwell”, appropriately broadcast in 1984 ("Charlotte Moorman Plays the TV Cello"). For this demonstration, Moorman performed in front of a green screen upon which was superimposed footage of a Parisian man whose face was being shaved, a manipulated live feed of Moorman, footage of Allen Ginsburg, and footage of a television broadcaster. All of this was also fed through the screens of the cello itself, but in an electronically manipulated negative form so that all the images appeared rather ghostly.

From the vantage point of the $21^{\text {st }}$ century, $T V$ Cello appears somewhat silly given our familiarity with more sophisticated digital video effects than were available to Paik in the 1970s. Indicative of Paik's mature compositional personality, however, TV Cello represents the coalescence of aural, visual, and performative elements that had never before come together in such a way. Moorman's performance of the cello directly affects the sound and image. Thus, performance becomes a meaning-generating force as it does in Cage's work. Here again, as in Manipulated Television, the Fluxus ideology of delegitimizing art emerges as the television is transformed by mechanical manipulation from a low-culture delivery device to an art object activated by performance.

I have examined some of Nam June Paik's compositions that, as I argue, reflect the aesthetic influence of John Cage and the ideology of the delegitimization of art as exemplified by Fluxus. I have identified a pattern of composition in which aural, visual, and performative elements are activated and made meaningful through performance, a notion that I suggest first entered Paik's compositional personality through his contact with Fluxus. Moreover, I argue that Paik's compositions are essentially musical, in a Cagean sense, in that they incorporate aspects of indeterminacy and "action music." However, it seems fairly certain that Paik never attempted the sort of methodical chance calculations characteristic of Cage. Indeed, Paik's work is so full of his whimsical personality that such a compositional technique would have changed his work completely. Like Cage, however, Paik's work represents a reaction against traditional artistic norms, and like Fluxus, Paik's work constantly comments upon the irrelevancy of elite art while simultaneously becoming elite art. 
Just as Cage's later work seems to recapture some sense of pre-1960s conventionality (especially in his "number" pieces that include a modified, though recognizable staff notation), so too did Paik's work seem to come down to earth. Large scale video installations in the 1980s and 1990s - not the least of which was a tower built of 1,003 working televisions created for the Seoul Olympics in 1988 - signal Paik's return to more fluid composition. In Venus, for example, twenty-four small video monitors are fed a frenetically edited and infinitely looped video from a laser disc player. Drawing a parallel to serialism, in which form remains conventional but dissonance is liberated, here too traditionally pleasing forms remain intact, though the information delivered through the video monitors is visually dissonant. What these later video works lack in comparison to the compositions I have described above, however, is an emphasis on performance. They are often referred to as "video sculpture." The installations generally require no performers apart from those who turn on the video monitors every morning.

Overall, Paik's work spans an extraordinarily wide expanse of time and material. Moreover, the philosophical implications are also equally profound. Paik strove to question the traditional roles of performer and audience, and in the process developed then radical ideas about the possibilities of technology for the connectivity of individuals. Paik was the first to use the term "Electronic Superhighway" in a piece from 1995 by the same name. Photos and a description of this piece can be found at ("Electronic").

\section{BIBLIOGRAPHY}

Auslander, Philip. "Fluxus Art-Amusement: Art-Amusement: The Music of the Future?" Contours of the Theatrical Avant-Garde: Performance and Textuality, edited by James Harding, University of Michigan Press, 2000, pp. 110-129.

Cage, John. Silence. M.I.T. Press, 1966.

"Charlotte Moorman Plays the TV Cello (1984)". YouTube, www.youtube.com/watch?v=r9hTdaFz36c. Accessed 13 September 2010.

Friedman, Ken, Owen Smith, and Lauren Sawchyn, editors. "The Fluxus Performance Work book. Performance Research,” www.performance-research.net/pages/e-publications.html. Accessed 15 September 2010.

Griffiths, Paul. Cage. Oxford University Press, 1981.

Hamlyn, Nicky. "Magnetic Memory: A Day-Long Video Tribute to Nam June Paik." Film Quarterly, vol. 60, no. 2, 2006, pp. 12-16.

“John Cage - Water Walk". YouTube, www.youtube.com/watch?v=SSulycqZH-U. Accessed 13 September 2010. 
Kellein, Thomas, and Toni Stooss. Nam June Paik: Video Time, Video Space. Harry N Abrams Inc, 1993. Paik, Nam June. "Expanded Education for the Paperless Society." Radical Software, vol. 1, 1970, pp. 7-8.

Paik Nam June. "TV Experiments". Between Two Worlds, btw2worlds.com/. Accessed 15 September 2010 .

Paik Nam June. "Electronic Superhighway: Continental U.S., Alaska, Hawaii." Smithsonian American Art Museum, americanart.si.edu/collections/search/artwork/?id=71478. Accessed 12 September 2010.

Paik Nam June, and John G. Hanhardt. The Worlds of Nam June Paik. Guggenheim Museum, 2000.

Shaw-Miller, Simon. The Visible Deeds of Music. Yale University Press, 2002.

\section{JOHN CAGE, FLUXUS I MUZYKALNOŚĆ NAM JUNE PAIKA}

\section{Streszczenie}

Niniejszy artykuł poświęcony jest analizie performance'u Nam June Paika. Autorka sugeruje, iż twórczość Paika, szczególnie po roku 1960, można uznać za wyjątkowo „muzyczną,” jeżeli spojrzy się na nią przez pryzmat Cage'owskiej muzyki-jako-działania. U Paika elementy słuchowe, wizualne i teatralne są zespolone w taki sposób, że performance staje się siłą jednoczącą i nadającą znaczenie. Autorka kończy artykuł argumentem, iż wpływ Cage’a był kluczowy, jeśli chodzi o rozwój dorobku twórczego Paika, skierowany w stronę eksperymentów w zakresie telewizji i wideo.

Słowa kluczowe: awangarda; sztuka video; performance; muzyka-jako-działanie; Fluxus.

\section{JOHN CAGE, FLUXUS AND THE MUSICALITY OF NAM JUNE PAIK}

\section{Summary}

In this paper, I offer an analysis of the performance art of Nam June Paik that suggests his works, especially those from the 1960s, are essentially "musical" when viewed through the influence of John Cage's notion of music-as-action. In Paik's work aural, visual, and theatrical elements are integrated such that performance becomes a unifying and meaning-generating force. I conclude by suggesting that Cage's influence set the tone for Paik's expansion into the experiments with television and video that would occupy him for the remainder of his career.

Key words: Avant-garde; video art; performance art; music-as-action; Fluxus. 